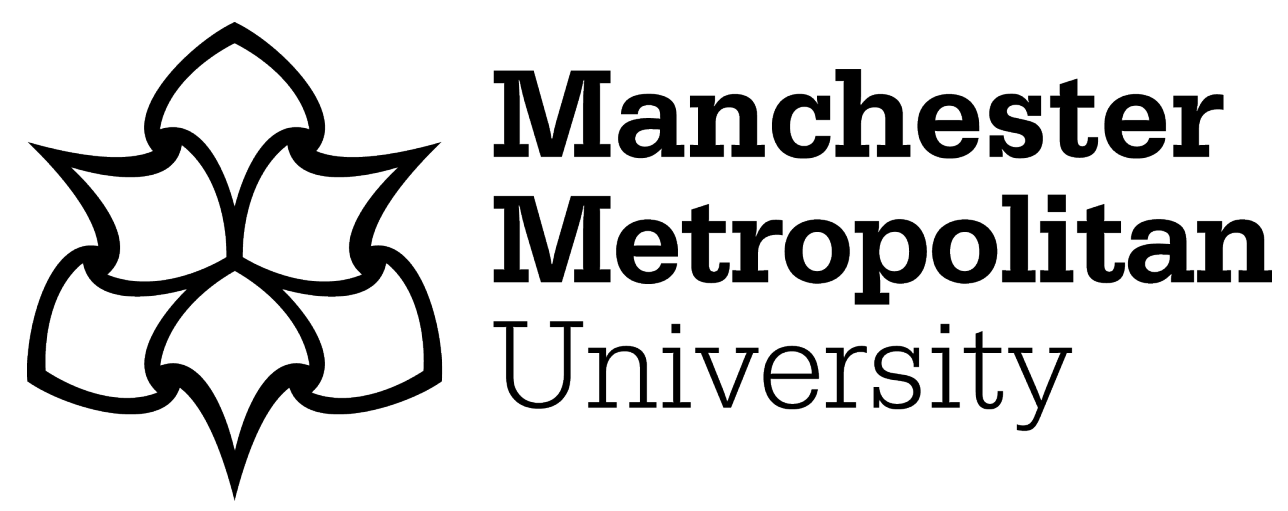

Solomon, Y ORCID logoORCID: https://orcid.org/0000-0002-2731-8380 (2012) Finding a voice? Narrating the female self in mathematics. Educational Studies in Mathematics, 80 (1-2). pp. 171-183. ISSN 0013-1954

Downloaded from: https://e-space.mmu.ac.uk/288598/

Version: Accepted Version

Publisher: Springer (part of Springer Nature)

DOI: https://doi.org/10.1007/s10649-012-9384-z

Please cite the published version 


\title{
Finding a voice? Narrating the female self in mathematics
}

\author{
Cite as: Solomon, Y. (2012) Finding a voice? Narrating the female self in \\ mathematics. Educational Studies in Mathematics 80(1-2) pp171-183
}

\begin{abstract}
If mathematics is a male domain, where does this leave women who do mathematics? In a world where there is little or no discursive space in which to be female, women who enter in must do identity work in order to achieve what is often an uneasy presence. This paper builds on recent research which suggests that some undergraduate women are however finding new spaces for belonging in the world of mathematics through critical reflection and collective challenge to dominant discourses. Focussing on an analysis of two women's narratives of their success in mathematics, it explores their multi-voiced accounts of self through the lens of Bakhtin's dialogism. It discusses the scope of reflexivity in creating new identity spaces in refigured worlds.
\end{abstract}

Women, university mathematics, identities, refiguring, heteroglossia

\section{Introduction: mathematics as a masculine domain}

Since Walkerdine's argument in Counting girls out (1989) that girls' underachievement in mathematics during the 1980's was constructed rather than real, much research has focussed on understanding the ways in which women are positioned as "successful but not succeeding" in mathematics. In recent years, although girls have begun to equal or outperform boys at school level in the UK, for example, they are under-represented in postcompulsory mathematics pre-university (see Mendick, 2005b) and in undergraduate and post-graduate study, where participation in mathematical sciences subjects falls to $41 \%$ and $27 \%$ respectively (HESA, 2011, table 7). This pattern is an international one, as Forgasz, Becker, Lee and Steinthorsdottir's (2010) book demonstrates, and it demands an understanding of women's own self-positioning as "not belonging" in the world of mathematics, even when they are successful in it at both undergraduate (Solomon, 2007a) and post-graduate (Herzig, 2004) levels. Theorising this situation, Mendick (2006) argues that "doing mathematics is doing masculinity": choosing mathematics and being good at it compromises femininity, requiring "identity work". One manifestation of this uneasy existence is invisibility: for Walls (2008), girls and women in mathematics "are required to don a cloak of invisibility that affords them temporary status as honorary males in a male domain" (p.4), and like Walkerdine before her, she notes the heavy psycho-social burden of this position. Similarly, Rodd and Bartholomew (2006) argue that the lack of a discursive space for women who do mathematics creates problems for those who choose it at degree level: since the available identities and cultural norms are masculine, young women can only position themselves as good at mathematics by stepping out of the available female identities. They are more likely to choose invisibility as a means of self-protection from the difficulties of "being a mathematical girl". Alternatively, they may play down their achievements, "tapping into discourses about mathematics learning which place 'real understanding' in opposition to 'memorization', and generally associate 'flair' with boys" (44). A parallel distinction is noted by Mendick et al. (2008), who report that undergraduates tend to divide mathematics sub-areas into "masculine" and "feminine", masculine areas being perceived as more "intellectual". Undergraduate women are correspondingly more likely to berate themselves for "not understanding" (Solomon, 2007a).

These studies underline Walls' (2009) claim that "boys and girls engage in their learning of mathematics at school as distinctly gendered social beings ... the subject of mathematics is itself constructive of children as gendered subjects" (p. 231). However, recent work (Solomon, Lawson, \& Croft, 2011) has suggested that some undergraduate women are establishing new discursive spaces which enable them to take up an identity of mathematician which does not exclude being female. Crucial elements in this shift have been the availability of physical spaces in some universities which have fostered collaborative learning practices, together with critical comment on, and challenge to, dominant discourses about mathematics which position men as more able. This paper explores further how two women's narratives of self as both mathematician and female are constructed, as 
a means of investigating the nature of resistance to discourses which construct mathematics as a masculine domain, and its role in a refiguring of women's identities within mathematics. It centres on an application of Holland, Lachicotte Jr, Skinner and Cain's (1998) theory of figured worlds, and the particular contribution of Bakhtin's emphasis on dialogism and heteroglossia to it. Analysis of the multiple and often contradictory voices that exist alongside each other within the interviews enables some conclusions regarding the interplay of reflexivity and refiguring within their accounts of the established world of mathematics and the "designated identities" (Sfard \& Prusak, 2005) which accompany it.

\section{Reflexivity and refiguring}

A number of writers have described the mathematics classroom as a figured world, "a socially and culturally constructed realm of interpretation in which particular characters and actors are recognized, significance is assigned to certain acts, and particular outcomes are valued over others" (Holland, et al., 1998, p. 52). Boaler and Greeno (2000, p. 173), for example, suggest that

A mathematics learning environment could be regarded as a particular figured world because students and teachers construct interpretations of actions that routinely take place there. ... The importance of this label for researchers of mathematics education resides in the characterization of a mathematics classroom as an interpretable realm, in which people fashion their senses of self. Figured worlds draw attention to interpretations by actors - students and teachers, for example - and to the rituals of practice. The mathematics classroom may be thought of as a particular social setting - that is, a figured world - in which children and teachers take on certain roles that help define who they are.

These rituals of practice and the relationships and relative positions of actors within the mathematics classroom have been catalogued by many - Schoenfeld (1989, p. 359) has produced a classic list describing traditional mathematics teaching which includes the solitariness of mathematical activity and the authority of the teacher, who has access to the one and only right answer. As many researchers have shown, there is also a gender dimension in the practices and positions of the classroom which are laid down in early schooling (see for example Black, 2004a, 2004b), continue in the later compulsory years (Boaler, 1997; Mendick, 2005a; Solomon, 2007b) and contribute to later marginalised identities (Hall, 2010; Solomon, 2009).

Nevertheless, there is some suggestion that the potential exists for change in women's (self-) positioning as mathematics learners. We have observed that some undergraduate women have taken particular advantage of collective spaces, and the opportunities for different roles and relationships that they bring, to carve out and exploit new ways of engaging in mathematics learning. As reported elsewhere (Solomon, Croft, \& Lawson, 2010), mathematics support centres appear to have a significant impact on discourses of ability and learning: they lead in particular to an appreciation of collaborative work and to a shift in attitudes towards university mathematics as a community of enquiry as opposed to an individual performance-oriented pursuit. This discursive shift towards valuing of collaboration over competition and recognition of the value contributed by all students appears to have a particular impact on women, who incorporate such discourses into a new, legitimised, positioning of self as mathematician: they are no longer "invisible". One particular effect of these new spaces is that they also enable or promote reflection on the figured world of mathematics in terms of an articulation of its unwritten rules and the nature of the identity positions that it affords. The bringing to consciousness of the "taken-for-granted" opens the way to critical comment and the potential for change, as described by Holland et al. (1998):

The everyday aspects of lived identities ... may be relatively unremarked, unfigured, out of awareness, and so unavailable as a tool for affecting one's own behavior. ... [But] Ruptures of the taken-for-granted can remove these aspects of positional identities from automatic performance and recognition to commentary and re-cognition. ... Some signs of relational identity become objectified, and thus available to reflection and comment.... Alternative figurings may be available for interpreting the everyday, and alternative ways of figuring systems of privilege may be developed in contestations over social arrangements. (Holland et al., 1998, pp. 140-142)

Such ruptures are, for Holland et al., the seeds of change in that they create new cultural resources for meaning making (p. 228). Thus while we can see the figured world of mathematics as one in which "gendered dispositions to participate, or not, in given activities, develop in places where gender participation in activities is treated as a claim of gender specificity" (p. 143), it is also the case that 
... positional identities are not without their disruptions. The same semiotic mediators, adopted by people to guide their behaviour, that may serve to reproduce structures of privilege and the identities, dominant and subordinate, defined within them, may also work as a potential for liberation from the social environment. .... When individuals learn about figured worlds and come, in some sense, to identify themselves in those worlds, their participation may include reactions to the treatment they have received as occupants of the positions figured by the worlds. (Holland et al., 1998, p.143)

In our data set there is indeed evidence that some students reflect on the gender dynamics of university mathematics by subjecting it to scrutiny and criticism. Other researchers have also noted the presence of a general critique of dominant discourses in mathematics: for example, in their study of mathematics in popular culture, Mendick et al. (2008, p. 33) report that "participants showed a critical awareness that the images they held of mathematicians were clichés and often both used them and distanced themselves from them". We can understand this awareness as an example of what Gee (2005, pp. 48-51) calls "Big 'C' conversations" - public debates of which we are aware through everyday exposure to the media and discussion with others. Recognition of the problem of stereotyping, including gender stereotyping, forms a background "Conversation" in much social interaction and it can be found in discussion about mathematics too. However, it is not clear how, or how far, this reflexivity impacts on individual identity and self-positioning within the figured world itself. In our data, we still see evidence of an on-going discourse of gender differences couched in terms of "natural" mathematical abilities. This is illustrated by Mendick et al.'s (2008) observation that women in mathematics take up spaces which men do not want to occupy - statistics and applied areas are seen as more "female" than pure mathematics, and they are frequently valued as correspondingly lesser mathematical activities. Thus it is possible that the carving out of female spaces within mathematics that we have witnessed is no more than a sideways shift within pre-existing gendered identity positions - so what role does, or can, reflexivity play in identity change in the figured world of mathematics?

\section{The dialogic self}

In order to make sense of this situation, and to explore the interplay of reflexivity and refiguring, I now turn to Bakhtin's emphasis on dialogism and the essential multiplicity of voices, or heteroglossia, in the authoring of self. As Holquist (2002, p. 18) insists, for Bakhtin,

In dialogism, the very capacity to have consciousness is based on otherness. This otherness is not merely a dialectical alienation on its way to a sublation that will endow it with a unifying identity in higher consciousness. On the contrary: in dialogism consciousness $i s$ otherness.

It is this otherness that underpins Bakhtin's treatment of voice. As Wertsch (1993, p. 52) points out, for Bakhtin, "meaning comes into existence only when two or more voices come into contact". Thus the concept of addressivity is fundamental in the authoring of self:

An essential (constitutive) marker of the utterance is its quality of being directed to someone, its addressivity. As distinct from the signifying units of a language - words and sentences - that are impersonal, belonging to nobody and addressed to nobody, the utterance has both an author ... and an addressee. This addressee can be an immediate participant-interlocutor in an everyday dialogue, a differentiated collective of specialists in some particular area of cultural communication, a more or less differentiated public, ethnic group, contemporaries, like-minded people, opponents and enemies, a subordinate, a superior, someone who is lower, higher, familiar, foreign, and so forth. And it can also be an indefinite, unconcretized other.... Both the composition and, particularly, the style of the utterance depend on those to whom the utterance is addressed, how the speaker (or writer) senses and imagines his addressees, and the force of their effect on the utterance. (Bakhtin, 1986, p. 95)

We can see here how important the social context is for Bakhtin. An utterance is, as Holquist (2002, p. 61) says, "a border phenomenon. It takes place between speakers, and is therefore drenched in social factors". In uttering, a speaker necessarily calls upon a social language. Bakhtin's focus on the fact that "the word in language is half someone else's" means that "it exists in other people's mouths, in other people's concrete contexts, serving other people's intentions: it is from there that one must take the word, and make it one's own" (Bakhtin, 1981, pp. 293294). However, this quality of multi-voicedness, the "ventriloquation" of one voice speaking through another, does not mean that the speaker is totally taken over. Bakhtin resists the idea of an individual who is totally determined by social context just as he resists that of the independent individual who creates meaning alone. It 
is a matter of gaining control over the word, expropriating it, to form a "hybrid construction", "an utterance that belongs, by its grammatical [syntactic] and compositional markers, to a single speaker, but that actually contains mixed within it two utterances, two speech manners, two styles, two 'languages', two semantic and axiological belief systems" (Bakhtin, 1981, p. 304). This process is far from straightforward, however:

And not all words for just anyone submit equally easily to this appropriation, to this seizure and transformation into private property: many words stubbornly resist, others remain alien, sound foreign in the mouth of the one who appropriated them and who now speaks them; they cannot be assimilated into his context and fall out of it; it is as if they put themselves in quotation marks against the will of the speaker. Language is not a neutral medium that passes freely and easily into the private property of the speaker's intentions; it is populated - overpopulated - with the intentions of others. Expropriating it, forcing it to submit to one's own intentions and accents, is a difficult and complicated process. (Bakhtin, 1981, p. 294)

Authoritative discourse - "the word of a father, of adults and of teachers...acknowledged scientific truth" (1981, pp. 342-3), and religious, political and modish texts - in particular resists such hybridising control. Unlike other voices, these voices of authority are non-negotiable, speaking with authority from the past:

The authoritative word demands that we acknowledge it, that we make it our own; it binds us.... Its authority was already acknowledged in the past. It is a prior discourse. It is therefore not a question of choosing it from among other possible discourses that are its equal. (p. 342)

In contrast, "internally persuasive" discourses - those which are "half ours and half someone else's" - present an opportunity for creativity:

... such a word awakens new and independent words, ... it organizes masses of our words from within, ... [it is], freely, developed, applied to new material, new conditions ... . More than that, it enters in an intense interaction, a struggle with other internally persuasive discourses. Our ideological development is just such an intense struggle within us for hegemony among various available verbal and ideological points of view, approaches, directions and values. The semantic structure of an internally persuasive discourse is not finite, it is open; in each of the new contexts that dialogize it, this discourse is able to reveal ever newer ways to mean. (pp. 345-346)

It is these newer ways to mean which are of particular interest here. Returning to Holland et al's account of identity and agency, we see how they draw on Bakhtin's (1981) account of the heteroglossic self-narrative together with Vygotsky's (1978) study of imaginary play-worlds of desire to emphasise the possibility of novelty and challenge. As Skinner, Valsiner, and Holland (2001) put it,

The author of a narrative generates novelty by taking a position from which meaning is made - a position that enters a dialogue and takes a particular stance in addressing and answering others and the world .... In weaving a narrative, the speaker places herself, her listeners, and those who populate the narrative in certain positions and relations that are figured by larger cultural meanings or worlds. Narrative acts may reinforce or challenge these figured worlds. [para 10]

In this account, the reflexivity which accompanies "ruptures of the taken-for-granted" becomes not only a source of resistance but also of alternative visions:

.. the 'metapragmatic' capability to figure social practice - through narrative, drawing, singing, and other means of articulation - is at the same time a capability to figure it otherwise than it is. (Holland et al.1998, p. 143, my emphasis)

In the next section, I explore the nature of reflexivity in two women's accounts of themselves as successful mathematics students, focusing on the inevitable multi-voicedness of their stories, and its role in reinforcing and/or challenging the figured world of mathematics and the identity positions that it affords.

\section{Choosing a language}

Consciousness finds itself inevitably facing the necessity of having to choose a language. With each literary-verbal performance, consciousness must actively orient itself amidst heteroglossia, it must 
move in and occupy a position for itself within it, it chooses, in other words, a 'language' (Bakhtin, 1981, p. 295).

The interviews discussed in this section build on an on-going project exploring undergraduate students' relationships with mathematics, drawing on survey data, interviews and focus groups spread across four universities. Findings from the larger data set and the details of the study are reported elsewhere (Solomon, 2007a, 2009; Solomon et al., 2010; Solomon et al., 2011). The two women who I focus on here were interviewed at a point where they were well established as university mathematics students. Joanne was at the end of a four-year undergraduate degree at a research-led university. This university operates an undergraduate system which can lead to a bachelor degree after three years, or a master's qualification after four years for stronger students who choose to do so. Joanne was a successful student who had taken the master's route and was on course to achieve a first class grading; her next step of $\mathrm{PhD}$ study in statistics in the same university was already decided upon. I had not met Joanne before, and her interview followed an unstructured format in which I asked her to tell me about her "maths biography"; it took place in my office, and was audio-taped. The interview lasted one hour and forty minutes. Roz had a different position in the study, having participated in focus group discussion on two previous occasions, during her second and third years in a three-year undergraduate programme at a "post-1992" university ${ }^{1}$. Her contribution to our analysis of the impact of space is described in Solomon et al. (2010). Roz had gained a first class degree and had been successful in gaining a place to study at master's level at a prestigious research-led university the following year, and had begun her $\mathrm{PhD}$ in mathematics in the year of her interview. We met at her university, in a neutral room near her office. The audiotaped interview lasted forty-five minutes, and was again an unstructured discussion of her "maths biography"; however it was also influenced by our shared experience of her earlier participation in the study three-four years before, and a focus on the group of women of which she was a part at that time.

The analysis develops separate narratives for each, focusing on the storying of self in terms of time and critical events, and reflexive responses to those events. I focus on the links they make to their personal histories and the voices of past and present, on the nature of reflexivity in their accounts, and the ways in which they situate their authored selves amidst heteroglossia. In the spirit of dialogism, it is of course necessary to recognise the fact that these interviews are not just a giving up of information by Joanne and Roz, but are joint constructions in which I played a part: my role as a researcher of mathematics education makes me a potential addressee with views that might be anticipated. I did not forefront my interest in gender, but again this might be anticipated. I shared a history of sorts with Roz, who knew that I was interested in her group. I begin with Joanne, who in some senses gives us a "base-line" insight into the figured world of undergraduate mathematics, from her position of being both within it but at the same time looking back from the point of view of her successful trajectory into the world of research mathematics. I then turn to Roz's story, which provides a main focus on ventriloquation and an authoritative discourse of gender differences, together with an insight into the struggles between discourses as Roz authors herself as a female mathematician.

\section{Joanne's story - the view from the inside}

Mathematics has featured in Joanne's life since before school. Very early on in her interview she tells me that both her parents were mathematics teachers, and that she and her sister had "little books" - "before we even went to school I was doing multiplication and division and stuff like that". There are tensions around this early experience it seems: Joanne says that her mother denies this memory, because "she always denies that she's ever pushed us to do anything but...". The pause and the rueful laugh which follow this appear to contradict Joanne's earlier claim that "they didn't push us to do it .... it was something that we liked to do". Although she tried "so hard" not to "follow in their footsteps", she has studied mathematics after all. However, she has eschewed mechanics ("disappointing" her mechanics-teacher mother) and is "proud" to be a statistician...

... because I've gone into stats which is probably a way of trying to distance myself from my parents because they were more the mechanics-y side ... then I think that once I've gone into the stats side that's the sort of point when 'yes I'm doing this' it's not because I have to it's because I want to ...

\footnotetext{
${ }^{1}$ Post-1992 universities in the UK were granted university status in 1992 as part of the expansion of Higher Education; most of these universities had previously been polytechnic colleges offering degree-level study, largely in technical/applied areas. They differ from older established universities in terms of having less strong research profiles, and greater emphasis on teaching; they also have less status.
} 
Joanne's account of her "current" self is illustrative of a narrative which addresses and answers her parents in an imagined and/or remembered dialogue stretching back into time, however much she may strive to distance herself. She is at the same time looking to the future, to a self separate from her parents, but her story is still populated by the arguments and agreements arising from her positional identity as their daughter. As she moves on to tell about her university career, she chooses words from that environment: she was quick, she says, to pick out people at her level, and she describes one particular student who was her benchmark or pacemaker - a constant source of comparison. But anticipating and answering a critique of competition, she asserts that she is not competitive:

I think it's always good to have somebody there that you can compare yourself with so that you know that you're still improving yourself.... it's not that I'm competitive it's that I like to know that I am constantly improving myself.

In the world which she describes, people "like to know what others are getting... there's a definite knowledge of who is ahead.... it's clear which people are the firsts".

These comparison points persist in Joanne's interview; talking about styles of working and the issue of group work which I am interested in because of my earlier findings, I ask if there are particular people who group together, and Joanne immediately responds in terms of how the students who populate her narrative are positioned in terms of the symbolism of degree classes which is so central in her world:

Low 2.1s, 2.2s I'd say [laughs] ... and normally you've got a high $2.1 /$ low 1 st person in there ... who is the one who will spot everyone else's mistakes...

YS: But people like you aren't using that because you don't need to [work in a group]?

For a lot of them because they've got quite good ability they've got used to the fact that people will try to take advantage if you know what I mean and just constantly use you for answers and that's one reason why they would try and stay away .... I would say that's why I don't work in a group, that's why I do work by myself...

The laugh which suggests that she is answering a voice which disapproves of the use of classification is followed up when Joanne suddenly changes course in this speech to describe helping another student, authoring herself as someone who likes to teach and who dislikes the classification of others by their likely class outcomes. Here she addresses me directly as an anticipated voice to be answered:

...but I am the type of person where if somebody asks me, like .... one of the 2.2 students (I hate, I hate classifying people like that but you know what I mean) [laughs] came to me and said 'look I'm really struggling with this do you mind if I come over and just go through it with you' and I don't mind doing that I really don't... and I was acting more like the teacher sort of like giving her hints and things .... I liked doing that ..... I'm looking forward to tutoring.

Multiple voices are also evident in what Joanne says about gender. In telling a story about women and spatial ability, she interjects with a counter-claim, and reflects on why she might position herself in terms of assumptions about gender differences:

... I'm not very good spatially.... We were in our exam and everybody tried to make [models] out of pieces of their exam paper - sorry I should say all the girls were doing that, guys weren't. .... I did find as well when I was a bit younger I was really good at spatial stuff like at (GCSE) I was quite good at spatial erm I don't know if it's subconsciously someone has told me I'm not good at it and therefore I think I'm not good at, no, but I was quite good ....

She draws other distinctions between men and women with respect to collaboration and competition which implicitly underline the absence of a space for herself as a high-scoring woman:

I'd say the women are more sociable with it, they tended to be the ones who organised the meetings to do course works.... to want to collaborate with the groups [YS you're talking about the 2.2/ 2.1 band here?] hmmmm they initiate it I'd say and the .... [She thinks about it all] I think there's a definite personality difference between the guys, the people who were getting the higher ... were people who were less sociable - [YS the higher scoring guys were less sociable?] yes. 
Joanne does not comment on this gap, however, and while she answers other dissenting voices she chooses very few in her story overall. Her narrative exposes many aspects of the figured world of undergraduate mathematics that we already know about - its competitiveness, the isolation, the fact that some students cluster together in groups for mutual support. Her authoring of self frequently draws on the dominant discourses and values of natural (and sometimes gendered) ability. However, we can also see in her language elements of reflexivity as she inserts asides which answer other voices calling into question the stratification of students by class and ideas about natural ability. Although she does not participate in the collaborative working practices that she sees initiated by women students, we do see her saying that she likes to teach, and that this reflects her personality and an associated ethos of care. In the end, though, my reading of Joanne is that as a successful student resourced by a family habitus which brings advantage in her world, she chooses a language which, while it contains elements of gender reflexivity, privileges the "old answers" to the voices which question her position.

\section{Roz's story - coming from behind}

Like Joanne, Roz talks about the affirmative role of mathematics in her identity, but in her case, mathematics was not on offer during her early life at all. She tells me that she was refused entry to Advanced Level (postcompulsory) mathematics at school, being predicted less than the required B grade in the public examinations at age 16. She returned to mathematics years later, studying alongside her sons, and carried on to further study at college. She describes her attendance at a master class at her local university as a critical event in her history, because it changed her view of what mathematics was, in human terms:

for the first time ever I realized that maths could make people's lives better - I always thought that mathematical research was about people inventing harder and harder sums to make people's lives more miserable and to have this idea that maths can describe the world and make it a better place for people was - just completely blew me away and that's where it all started and that's why I'm here now I think.

At university, she became "completely hooked" on mathematical modelling, and began a consistently successful undergraduate career - "top of the year three years out of three" - which fed a desire to study further:

... half way through my second year it became obvious that three years wasn't going to be anything like enough - this was far too interesting and erm... it was like coming over the brow of the hill and suddenly realising there was a whole vista of things to explore ....

Now a post-graduate at a prestigious university, Roz explicitly answers the voices from her past as she selfauthors as someone who, unlike Joanne, is permanently struggling and is amazed by her progress:

I always feel like I'm struggling, ... If you'd told me three years ago I'd get a masters degree from X university I'd have laughed in your face, if you had told me 5 years ago I was going to do a degree in mathematics and get a first I'd have laughed in your face .... because I think when people say negative things about my ability those are the things that typically I retain. [YS: so it stuck?] Oh yes, very much so... Every time I struggled with something this voice would come back you know 'you're no good at maths, you won't do it, you won't cope', that was their words, 'if it was more like O level then you'd be fine but it's not..' ... [but ] I will believe that I can't do it when I try and fail...

As she remembers and relives these earlier judgements and the emotions that accompanied them, Roz answers with a defiance which challenges the ideology which values grades over interest and competition over collaboration. As noted above, one of the main reasons for my interest in her story is the role she played as a prominent member of a successful group of five undergraduate women, all of whom went on to get first class degrees. She refers back to this group now, building a story of their operation as a single unit, and in doing so she reflects on gender differences in the undergraduate mathematics world:

It was almost always one of the five of us who got the got the top marks, we used to call ourselves the A team.... but I think there is a certain element that likes to be competitive in the men whereas when we were a little group we worked together to revise for tests and things like that and I could genuinely be pleased when X got more marks than I did and so on - so long as one of us got it, it was in the family....

Like Joanne, Roz says she is not competitive.... 
I'm not kidding myself, of that little group I was not the top, I mean I'm the one who's gone on to do post grad at the moment but that's just the way things happened really, any of them could do it probably better than I could if they wanted to. So ... there isn't the same competitive edge, I don't feel competitive.

... but this claim is located within other voices - "the family" in which she is the mother, a role she plays in her everyday life ("it's very much the whole mothering thing, like, because I have three sons I can be pleased for them that they've done well"), and a counter-voice against masculine values. The force of the group's collective "figuring otherwise" is such that it was possible to incur disapproval by acting more like men:

... to be in it for yourself was an insult within the context - as a phrase, 'oh they're in it for themselves' was really an insult within our little group, to be in it for yourself, not to be cooperating with the group or helping, you've got some insight that you're not sharing or some piece of information that you're not sharing, then that was seen to be disloyal.

However, Roz's self-authoring as a female (and mature) mathematician reaches a new level of complexity as she addresses the equality agenda by asserting the benefits of the very same semiotic mediators of femininity which may serve to exclude:

There was a lady, the only time we ever had a lady lecturer..... everybody hated her ..... because she didn't dress properly. And this was a big thing for a lot of the girls, she looked like she was just doing her housework... she was wearing flat shoes or trainers with socks and trousers which didn't quite reach her trainers ... When I started lecturing ... I thought 'it's important to them that I dress professionally' and I see myself as - you know - females are underrepresented in mathematics anyway, so ... people must understand they don't have to give up being a woman to be a mathematician ...

Competing internally persuasive discourses can be seen in this somewhat perplexing heteroglossic passage, in which Roz appears to have lost control of what she introduces as a feminist standpoint. What she says here seems to provide direct support for the argument that, for women, "doing maths is masculinity" and that it requires identity work - and therefore that there is no real space for being a female and a mathematician, despite what Roz has said earlier in overt criticism of what she sees as masculine values and support of her own noncompetitive ones. Arguably, Roz is struggling here to hybridise dominant gender discourses and to submit them to her own accent, as Bakhtin puts it. Indeed, she takes her discussion of gender further to explain her sense of new belonging in the world of mathematics in contrast to her early isolation as a child, drawing explicitly now on the words of others:

I have a theory - The essential difference by Simon Baron-Cohen? .... I did the tests and I have a male brain ... maybe because I have a male brain I was not picking up the unspoken signals of my female group .... so I was very isolated, and very often I've been in social situations where I felt I was doing the wrong thing and I didn't know what it was. However, when I got to [university], majority male, I was completely in the right place and all of a sudden it was OK to be me. Because the backdrop is majority male, then I'm female in that context, but if I'm in with a lot of very feminine women then I'm not, and there are a lot of things that are typical of women that I don't like.

We can see this turn in Roz's story as one in which she is overwhelmed by the "authoritative discourse" of a currently fashionable book which "permits no play with the context framing it, no play with its borders, no gradual and flexible transitions, no spontaneously creative stylizing variants on it. It enters our verbal consciousness as a compact and indivisible mass" (Bakhtin, 1981, p.343). Here, it seems certain that she is unable to hybridize this discourse with the ideology of collaboration and non-competitiveness which she has articulated so clearly in her own words before. She goes on to make a sharp evaluative division between men and women which is applied not only to everyday life (fashion, shopping) but also indirectly, but crucially, to mathematics, as she gives voice to another discourse about analytical thought:

...because I'm in a male context my femininity looks like femininity whereas if I'm in a very female context I feel like the man almost ... I feel at the male end of the perspective, I'm thinking analytically, I'm thinking ..'does that really hold?', this kind of thinking process, analysing things, and I really can't get excited about shopping I really can't and I can talk about fashion for maybe three minutes. ... It really is trivial ... with men that really doesn't come up and the things that they talk about are really interesting. 
Thus Roz's self-authoring draws on discourses about mathematics as gendered and on a particular text which identifies her as both male and female, separating out brain from body and providing her with a picture of herself as a female mathematician which does not blend with her narrative of "the A-team", her personal history of challenging teachers who sought to write her off, or her reflexive reference to gender issues in mathematics. At this precise moment in time she struggles to establish an authorial stance - "a voice that over time speaks categorically and/or orchestrates the different voices in roughly comparable ways" (Holland et al., p.182).

\section{New identity spaces: "figuring it otherwise"}

My intention in this paper has been to explore the role of reflexivity in the figured world of mathematics, and in the identity spaces that it affords, by considering voices of challenge and critique in terms of the part they play in heteroglossic self-narratives. As we have seen, there is no easy link to be made between reflexive accounts of gender and ability and a change in the (self-)positioning of women in mathematics - despite their reflexivity, mathematics is still portrayed as gendered, as a masculine field.

However, Bakhtin's emphasis on the ever presence of multiple voices means that there is always potential for new meanings as we self-author within new imagined spaces. Joanne, as I have said, appears to be sensitised to issues of gender and equality, but does not herself confront them - drawing on her family background, she moves in the world of mathematics unproblematically and uncritically it seems. Perhaps it would be true to say that in so far as we see heteroglossia in her story, it is also the case that she is able to hybridise the voices of reflexive dissent, to expropriate them and use them to answer anticipated criticism of the competitiveness and belief in natural ability which serves her own ends. Roz's story, however, is one of struggle from the outset, and while she is strikingly ventriloquated by the authoritative voice of "the male brain", she continues her dialogue with the distant voices of the past, and they remain highly visible in her self-authoring. Like Holland et al.'s Nepali girls who 'retained vivid memories of abrupt encounters with [expectations of 'the good woman'] - memories of the particular people who scolded them, of their feelings of shame and anger" (p. 226), Roz retains the memories of having been denied access to mathematics. These contribute to the dialogic process of self-authoring which includes an imagined world of collaboration, and appears in her strong advocacy of the ethos of the "A-team". It is this dialogic space which enables alternative worlds:

Activity predicated upon a figured world is never quite single, never quite pure. It is dialogized, figured against other possible positions, other possible worlds. ... The space of freedom that is the space of play between these vocations is the space of the author. .... Here people create new orchestrations from the play of inner speaking and seek to convert them interactively to new imagined practices, new virtualities. (Holland et al, p.238)

Thus, it seems that it is Roz's more overt struggle in choosing a language, rather than Joanne's rather smoother hybridisation, that suggests that "figuring it otherwise" is still on the agenda. Roz's story as constructed with me as her interlocutor on that occasion is not fixed; indeed the act of telling becomes part of her story as it happens, and enters her past. As Holquist (2002, p. 38) points out, the dialogic "I" "bears within it the seeds of hope": because dialogue is composed not merely of utterance and reply, but also the relation between these two, existence is not limited to the current time and place and the limits that they impose on the possible range of self/other relations, "for in later times, and in other places, there will always be other configurations of such relations, and in conjunction with that other, my self will be differently understood". Thus "dialogism is ultimately an epistemology founded on a loophole" (p. 39). As Bakhtin puts it:

There is there is neither a first nor a last word and there are no limits to the dialogic context (it extends into the boundless past and the boundless future). Even past meanings, that is, those born in the dialogue of past centuries, can never be stable (finalized, ended once and for all) - they will always change (be renewed) in the process of subsequent, future development of the dialogue. At any moment in the development of the dialogue there are immense, boundless masses of forgotten contextual meanings, but at certain moments of the dialogue's subsequent development along the way they are recalled and invigorated in renewed form (in a new context). Nothing is absolutely dead: every meaning will have its homecoming festival. (1986, p. 169) 


\section{References}

Bakhtin, M. (1981). The dialogic imagination: Four essays by M.M. Bakhtin (C. Emerson \& M. Holquist,Trans.). Austin: University of Texas Press.

Bakhtin, M. M. (1986). Speech genres and other late essays (V. W. McGee, Trans.). Austin: University of Texas Press.

Black, L. (2004a). Differential participation in whole-class discussions and the construction of marginalised identities. Journal of Educational Enquiry, 5(1), 34-54.

Black, L. (2004b). Teacher-pupil talk in whole-class discussions and processes of social positioning within the primary school classroom. Language and Education, 18(5), 347-360.

Boaler, J. (1997). Experiencing school mathematics: teaching styles, sex and setting. Buckingham: Open University Press.

Boaler, J., \& Greeno, J. G. (2000). Identity, agency, and knowing in mathematics worlds. In J. Boaler (Ed.), Multiple perspectives on mathematics teaching and learning (pp. 171-200). Westport, CT: Ablex publishing.

Forgasz, H., Becker, J. R., Lee, K.-H., \& Steinthorsdottir, O. (Eds.). (2010). International perspectives on gender and mathematics education. Charlotte, NC: Information Age.

Gee, J. (2005). An introduction to discourse analysis: Theory and method (2nd ed.). London: Routledge.

Hall, J. (2010). The influence of high school and university experiences on women's pursuit of undergraduate mathematics degrees in Canada. In H. Forgasz, J. R. Becker, K.-H. Lee \& O. Steinthorsdottir (Eds.), International perspectives on gender and mathematics education (pp. 365-389). Charlotte, NC Information Age.

Herzig, A. H. (2004). "Slaughtering this beautiful math": Graduate women choosing and leaving mathematics. Gender and Education, 16(3), 379-395.

HESA (2011). Statistical First Release 153 Higher education student enrolments and qualifications obtained at higher education institutions in the united kingdom for the academic year 2009/10. Retrieved 20/11/11, from Higher Education Statistics Agency:

http://www.hesa.ac.uk/index.php?option=com_content\&task=view\&id=1936\&Itemid=161

Holland, D., Lachicotte Jr, W., Skinner, D., \& Cain, C. (1998). Identity and agency in cultural worlds. Cambridge, Massachusetts: Harvard University Press.

Holquist, M. (2002). Dialogism: Bakhtin and his world (2nd ed.). London: Routledge.

Mendick, H. (2005a). A beautiful myth? The gendering of being/doing "good at maths". Gender and Education, 17(2), 203-219.

Mendick, H. (2005b). Mathematical stories: why do more boys than girls choose to study mathematics at ASlevel in England? British Journal of Sociology of Education, 26(2), 225-241.

Mendick, H. (2006). Masculinities in mathematics. Berkshire: Open University Press.

Mendick, H., Moreau, M.-P. \& Hollingworth, S. (2008) Mathematical images and gender identities. Report for UK Resource Centre for Women in Science, Engineering and Technology (UKRC).

Rodd, M., \& Bartholomew, H. (2006). Invisible and special: young women's experiences as undergraduate mathematics students. Gender and Education, 18(1), 35-50.

Schoenfeld, A. (1989). Explorations of students' mathematical beliefs and behavior. Journal for Research in Mathematics Education, 20, 338-355.

Sfard, A., \& Prusak, A. (2005). Telling identities: in search of an analytic tool for investigating learning as a culturally shaped activity. Educational Researcher, 34(4), 14-22.

Skinner, D., Valsiner, J., \& Holland, D. (2001). Discerning the dialogical self: A theoretical and methodological examination of a Nepali adolescent's narrative Forum: Qualitative Social Research, 2(3). Retrieved 20/11/11 from http://www.qualitative-research.net/fqs-texte/3-01/3-01 skinneretal-e.htm

Solomon, Y. (2007a). Not belonging? What makes a functional learner identity in the undergraduate mathematics community of practice?' Studies in Higher Education, 32(1), 79-96. 
Solomon, Y. (2007b). Experiencing mathematics classes: gender, ability and the selective development of participative identities. International Journal of Educational Research 46(1/2), 8-19.

Solomon, Y. (2009). Mathematical literacy. developing identities of inclusion. London and New York: Routledge.

Solomon, Y., Croft, A., \& Lawson, D. (2010). Safety in numbers: mathematics support centres and their derivatives as social learning spaces. Studies in Higher Education, 35(4), 421 - 431.

Solomon, Y., Lawson, D., \& Croft, A. (2011). Dealing with "fragile identities": resistance and refiguring in women mathematics students. Gender and Education, 23(5), 565 -558

Vygotsky, L. (1978) Mind in society. Cambridge, Mass: Harvard University Press

Walkerdine, V. (1989). Counting girls out. London, UK: Virago.

Walls, F. (2008). Girls, mathematics and the gendered construction of mathematical (dis)ability. Paper presented at the PME. Retrieved 20/11/11 from http://www.pme32na30.org.mx/ws1/Gender\%20and\%20Mathematics\%20book\%20Abstract-walls.pdf

Walls, F. (2009) Mathematical subjects: children talk about their mathematics lives. Dordrecht: Springer

Wertsch, J. V. (1993). Voices of the mind. Cambridge, Mass: Harvard University Press. 